\title{
QUANTITATIVE ANALYSIS OF EXPRESSION LEVEL OF BCL2 AND BAX GENES IN HEP-2 AND HL-60 CELLS AFTER TREATMENT WITH ETOPOSIDE
}

\author{
Dita Královcová ${ }^{1}$, Marcela Pejchalová ${ }^{1}$,Emil Rudolf ${ }^{2}$, Miroslav Červinka $^{2}$
}

University of Pardubice, Faculty of Chemical-Technology, Czech Republice: Department of Biological and Biochemical Sciences ${ }^{1}$; Charles University in Prague, Faculty of Medicine in Hradec Králové, Czech Republic: Department of Medical Biology and Genetics ${ }^{2}$

\begin{abstract}
Summary: Apoptotic cell death is a highly regulated process, which plays a crucial role in many biological events. The aim of the present research was to investigate the expression of the apoptosis related genes BCL2 and BAX in Hep-2 and HL60 cells. Apoptosis was induced in these cell lines during treatment with etoposide. The expression levels of BCL2 and BAX genes were measured after $6 \mathrm{~h}$ and $12 \mathrm{~h}$ of treatment by quantitative real-time RT-PCR. In Hep-2 cells the expression level of BCL2 significantly increased both $6 \mathrm{~h}$ and $12 \mathrm{~h}$ of treatment, whereas expression level of BAX didn't change. In HL-60 cells the expression level of BCL2 decreased after $6 \mathrm{~h}$ of treatment and expression of BAX increased both $6 \mathrm{~h}$ and $12 \mathrm{~h}$ of treatment with etoposide. Those findings show distinct reactions of Hep- 2 and HL-60 cells to etoposide treatment and different upregulation or downregulation of apoptosis-related genes BCL2 and BAX.
\end{abstract}

Key words: Apoptosis; Etoposide; BCL2, BAX; Real-time RT-PCR

\section{Introduction}

Many cytostatic drugs have been reported to induce apoptosis in tumor cells both in vitro and in vivo (1, 27, 30). Apoptosis is a complex, strictly regulated physiological process which is characterized by several molecular and biochemical features such as upregulation of proapoptotic genes, activation of specific enzymes, degradation of subcellular organelles, cell contraction and rounding, formation of spikes and blebs, DNA fragmentation and cell fragmentation into apoptotic bodies (19).

Apoptosis is also involved in cancer therapy and many chemotherapeutic agents act by induction of apoptosis. For example etoposide, which was used in our study, belongs to the most commonly used classes of anticancer drugs and it has a broad anti-tumor spectrum. The drug increases level of topoisomerase II-mediated DNA breaks and it acts by inhibiting the ability of topoisomerase II to ligate cleaved DNA molecules (3).

Etoposide can induce apoptosis in human tumor cell lines Hep- 2 and HL-60 and this process is accompanied by typical morphological changes as a cell blebbing, DNA fragmentation and changes in mitochondrial potential (5, 25). These morphological changes in apoptotic cells are accompanied with changes in expression of apoptosis-related genes $\operatorname{BCL} 2$ and $\operatorname{BAX}(12,8)$. During apoptosis is
BAX transported to the mitochondria and induces the release of cytochrome $\mathrm{c}$ from the mitochondria. Released cytochrome $\mathrm{c}$ binds APAF1 and CASP9 and induces apoptosis in the cells $(10,20)$. On the other hand, BCL2 binds to BAX and can forms heterodimers, thus inhibiting BAX activity. The ratio of BCL2 to BAX protein has been reported to be correlated with apoptosis in cancer cells $(9,22)$. Expression level of these apoptosis-related genes is various and depends on the type of cell lines. The analysis of changes of expression levels of BCL2 and BAX genes may provide new information about the chemo-resistance or chemo-sensitivity (16). Expression level could also differ between tumor and noncancerous samples (15, 29).

In the present study we investigated the occurrence of changes in the expression levels of apoptosis-related genes (BCL2 and BAX) in cancer cell lines Hep-2 and HL-60 during etoposide treatment.

\section{Materials and Methods}

Cell lines and cytostatic

Etoposide (Vepesid inj., Bristol-Myers Squibb, USA) was diluted from the original ampoules supplied by manufacturer in a serum-free DMEM to the tested concentration of the $10 \mu \mathrm{g} / \mathrm{ml}$. 
Human epitheloid cell line Hep-2 (ECACC, No. 86030501, Porton Down, England) was cultivated as stationary monolayer in plastic tissue-culture dishes (Nunclon, Denmark). Cells were grown in Dulbecco's modified Eagle's medium (Gibco, Germany) supplemented with $10 \%$ fetal serum (Gibco, Germany), $100 \mathrm{U} / \mathrm{ml}$ penicillin, and 100 $\mu \mathrm{g} / \mathrm{ml}$ streptomycin.

Human promyelocytic leukemia HL-60 cells (ECACC, No. - 85011431, Porton Down, England) were grown in RPMI 1640 medium (Gibco, Germany) supplemented with $10 \%$ fetal calf serum (Gibco, Germany), $100 \mathrm{U} / \mathrm{ml}$ penicillin, and $100 \mu \mathrm{g} / \mathrm{ml}$ streptomycin.

Cells were grown under standard laboratory conditions $\left(37{ }^{\circ} \mathrm{C}, 5 \% \mathrm{CO}_{2}\right)$. After 24 hours of cultivation cells in a control group were harvested and washed with PBS. In groups were the effect of etoposide on Hep-2 and HL-60 cells was investigated, the standard medium was replaced with a medium containing $10 \mu \mathrm{g} / \mathrm{ml}$ of etoposide. After incubation for 6 and 12 hours, cells were harvested and washed with PBS.

\section{Quantitative PCR analysis}

Total RNA was extracted using NucleoSpin RNA II kit (Macherey -Nagel, Germany), according to the manufacturer's protocol. Total RNA was eluted with $50 \mu \mathrm{l}$ of RNAse free water and stored at $-70{ }^{\circ} \mathrm{C}$. The RNA concentration was determined using spectrophotometry. Complementary DNA (cDNA) was synthesized with $1 \mu \mathrm{g}$ total RNA and 0,8 $\mu$ g oligo (dT) 12-18 primer (Generi-Biotech, Czech Republic), 200 U M-MuLV Reverse Transcriptase (Finnzymes, Finland) and $40 \mathrm{U}$ of RNasin Ribonuclease Inhibitor (Promega, USA) per reaction.

Primers and the TaqMan probes for detecting gene expression of BAX and PBGD by real-time PCR were designed and synthesized by Generi-Biotech (Czech Republic), sequences of primers for BCL2 were taken from Ikeguchi et al. (16) and synthesized by Generi-Biotech (Czech Republic) (Tab. 1).

Quantification of gene expression was performed with RotorGene 3000 detection system (Corbett Research, Australia). PCR solution $(20 \mu \mathrm{l})$ was composed of $1 \mu \mathrm{l}$ cDNA, $5 \mathrm{mM} \mathrm{MgCl}_{2}, 0.2 \mathrm{mM}$ of each dNTP, $1.25 \mathrm{U}$ of Thermo-Start DNA Polymerase (AB gene, UK) forward primer $300 \mathrm{nM}$, reverse primer $900 \mathrm{nM}$ and FAM probe
$100 \mathrm{nM}$ (PBGD), forward primer $900 \mathrm{nM}$, reverse primer $900 \mathrm{nM}$ and FAM probe $100 \mathrm{nM}$ (BCL2), forward primer $300 \mathrm{nM}$, reverse primer $300 \mathrm{nM}$ and FAM probe $100 \mathrm{nM}$ (BAX). The thermal cycle parameters were: 1 . cycle $95^{\circ} \mathrm{C}$ for $15 \mathrm{~min}$ followed by 45 cycles at $95{ }^{\circ} \mathrm{C}$ for $20 \mathrm{sec}, 60^{\circ} \mathrm{C}$ for $40 \mathrm{sec}$.

Standard curves for BAX, BCL2 and PBGD were generated using serial dilution of cDNA derived from the cell lines. PBGD was monitored as a reference gene and BCL2 and BAX expression levels were normalized with respect to PBGD transcript and calculated by $2^{-\Delta \Delta \mathrm{Ct}}$ method (21).

All experiments were repeated three times and statistical analysis was done with the program QC. Expert 3.0 (TriloByte, Czech Republic). A two-sided P-value, lower than 0.05 was considered as statistically significant difference.

\section{Results}

In Hep-2 cells, the relative expression level of antiapoptotic BCL2 gene was significantly higher after $6 \mathrm{~h}$ of treatment than the untreated control $(p=0.048)$. The relative expression level of BCL2 was significantly higher also after $12 \mathrm{~h}$ of treatment $(\mathrm{p}=0.001)$ and the expression level also significantly increased between $6 \mathrm{~h}$ and $12 \mathrm{~h}$ of treatment ( $p=0.03$ ) with etoposide (Fig. 1). Whereas, the relative expression level of proapoptotic BAX did not significantly change neither after $6 \mathrm{~h}$ nor $12 \mathrm{~h}$ of treatment with etoposide (Fig. 2)

In HL-60 cells, the relative expression level of antiapoptotic BCL2 gene was significantly lower after $6 \mathrm{~h}$ of treatment than the untreated control $(p=0.013)$, but the expression level after $12 \mathrm{~h}$ of treatment was significantly higher $(p=0.012)$ compared to untreated control. The significant distinction was also between 6 and $12 \mathrm{~h}(\mathrm{p}=0.0003)$ of treatment with etoposide (Fig. 3). The relative expression level of proapoptotic BAX gene was significantly higher after $6 \mathrm{~h}(\mathrm{p}=0.007)$ and $12 \mathrm{~h}(\mathrm{p}=0.0009)$ of treatment with etoposide compare to untreated control (Fig. 4).

\section{Discussion}

Etoposide induces apoptosis in various cancer cell lines $(14,17,18,23)$. To investigate the mechanism of apoptosis

Tab. 1: Sequences of the oligonucleotide primers and probes used in real-time RT-PCR assays.

\begin{tabular}{|l|l|l|c|}
\hline Target gene & Function & Sequence & PCR product size (bp) \\
\hline \multirow{4}{*}{ BCL2 } & Forward primer & 5'-TTGGCCCCCGTTGCTT-3' & 65 \\
\cline { 2 - 4 } & Reverse primer & 5'-CGGTTATCGTACCCCGTTCTC- 3' & \\
\cline { 2 - 4 } & Probe & 5'-AGCGTGCGCCATCCTTCCCAG-3' & 124 \\
\hline \multirow{3}{*}{ BAX } & Forward primer & 5'-GTCGCCCTTTTCTACTTTGCCAG-3' & \\
\cline { 2 - 4 } & Reverse primer & 5'-TCCAGCCCAACAGCCGCTCC- 3' & 106 \\
\cline { 2 - 4 } & Probe & 5'-CCAATGTCCAGCCCATGATGGTTCTGA-3' & \\
\hline \multirow{2}{*}{ PBGD } & Forward primer & 5'-ACCATCGGAGCCATCTGCAAG-3' & \\
\cline { 2 - 4 } & Reverse primer & 5'-CCCACCACACTCTTCTCTGGCA-3' & \\
\cline { 2 - 4 } & Probe & 5'-CCCTCATGATGCTGTTGTCTTTCACCCAA-3' & \\
\hline
\end{tabular}




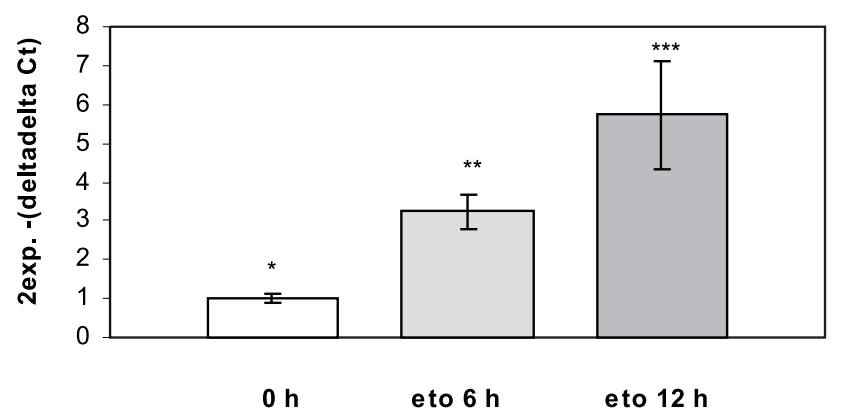

Fig. 1: Hep-2, BCL2/PBGD ratio.

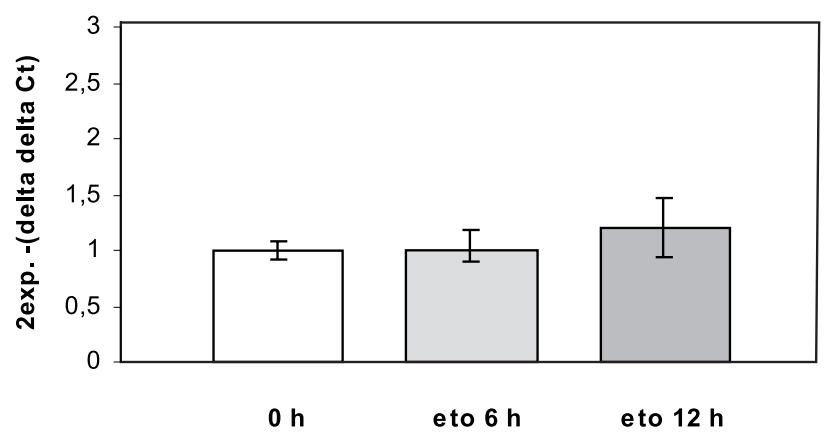

Fig. 2: Hep-2, BAX/PBGD ratio.

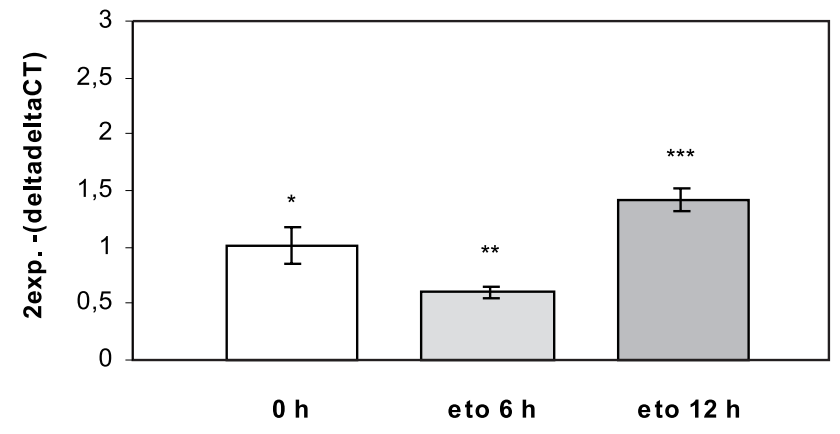

Fig. 3: HL-60, BCL2/PBGD ratio.

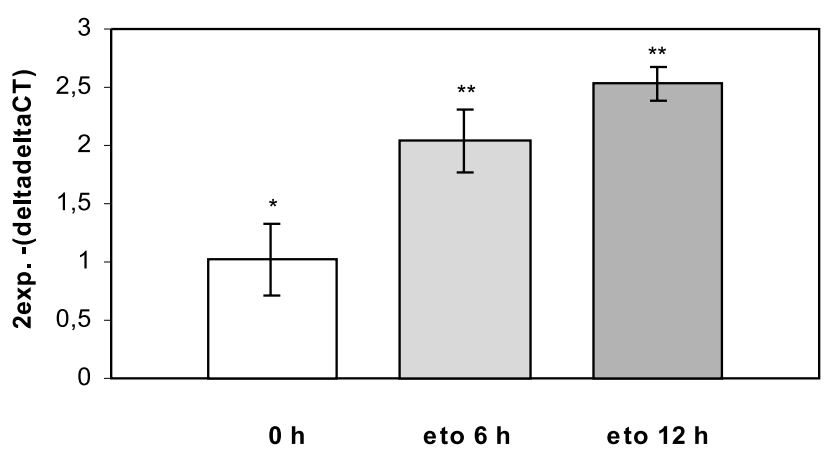

Fig. 4: HL-60, BAX/PBGD ratio.

Fig. 1-4: Relative expression of apoptosis-related genes during treatment with etoposide. A significant difference $(p<0.05)$ was detected between $* * *$ and $* * *$.

the expression levels of apoptosis-related genes (BCL2 and BAX) were analyzed in cancer cells lines Hep-2 and HL-60 during etoposide treatment.

Etoposide is one of the most widely prescribed anticancer drugs in the world. It is used to treat a variety of cancers, including small cell lung cancer, sarcomas, leukemias and lymphomas. Etoposide is derived from podophyllotoxin, the natural product from the plant Podophyllum peltatum. The primary cellular target for etoposide is topoisomerase II. This essential enzyme removes knots and tangles from the genome by introducing transient doublestranded breaks in the DNA strand. The effect of etoposide is in a stabilization of covalent enzyme-cleaved DNA complex (known as the cleavage complex) which is an intermediate in the catalytic cycle of topoisomerase II. The accumulation of cleavage complexes in treated cells leads to the generation of permanent breaks in the genetic material, which finally trigger cell death (3).

Induction of apoptosis in Hep-2 cells was described in previous work of Črvinka et al. (5). Cells were treated with etoposide at $10 \mu \mathrm{l} / \mathrm{ml}$ concentration. In the period of 4-8 $\mathrm{h}$ after beginning of the treatment the cell becomes rounded and plasma membrane formed numerous of pseudopodia. Typical formation of DNA ladders due to an internucleosomal hydrolysis of the DNA was also observed. In the following works they described other typical hallmarks of apoptosis such as membrane blebbing and activa- tion of caspase 3 in Hep- 2 cells after treatment with etoposide $(6,25,26)$. So these data show, that etoposide of concentration $10 \mu \mathrm{l} / \mathrm{ml}$ can induce typical apoptotic changes in Hep-2 cells. Duran et al. (7) also observed typical morphological changes such as granulation, nuclear enlargement and rounding of Hep-2 cells after treatment with etoposide at $5 \mu \mathrm{l} / \mathrm{ml}$ and $50 \mu \mathrm{l} / \mathrm{ml}$ concentration.

Quantitative real-time RT-PCR analysis showed that expression level of BCL2 gene significantly increased both $6 \mathrm{~h}$ and $12 \mathrm{~h}$ after treatment with etoposide in Hep-2 cells. Whereas the expression level of BAX did not significantly changes neither after $6 \mathrm{~h}$ or $12 \mathrm{~h}$.

These results do not correspond with ours expectations about induction of apoposis in Hep-2 cells. However, apoptosis is a complex process and can be induced by other genes of BCL2 family which were not analyzed.

References about induction of apoptosis in Hep-2 cells with etoposide or about expression of BCL2 and BAX genes are very rare. Some authors report about downregulation of BCL2 protein after induction of apoptosis in Hep-2 cells with venom from lionfish (2) or after induction of apoptosis with carboplatin and 5-fluorouracil (28). The similar results, but in PANC-1 cells, has been reported by Ikeguchi et al. (16). The expression levels of BCL2 increased and BAX expression level did not changes during cisplatin treatment, so overexpressing of BCL2 gene may play an important role in the chemo-resistance of PANC-1 cells. 
Induction of apoptosis in HL-60 cells was described in previous work of Rudolf et Červinka (25). Cells were treated with etoposide at $10 \mu \mathrm{l} / \mathrm{ml}$ concentration which induced typical cell blebbing and subsequent cell death. Induction of apoptosis in HL-60 cells after treatment with etoposide was also described by many others authors. Higginbottom et al. (14) induced apoptosis in HL-60 cells after incubation with etoposide at concentrations $1 \mu \mathrm{l} / \mathrm{ml}$ and $10 \mu \mathrm{l} / \mathrm{ml}$ for $6 \mathrm{~h}$ and the cleavage of caspase 9 was indicative of apoptotic cell death. Kravtsov et al. (19) treated HL-60 cells with $1,2.5,5,10$ and $20 \mu \mathrm{mol} / \mathrm{L}$ concentration of etoposide and the most effective in apoptosis induction was $10 \mu \mathrm{mol} / \mathrm{L}$. Typical morphological changes such as membrane blebbing were also observed. Eliseev et al. (8) described morphological changes such as membrane blebbing, condensation of chromatin and fragmentation of DNA in HL-60 cells during treatment with $50 \mu \mathrm{M}$ etoposide. Zuryn et al. (30) induced apoptosis in HL-60 with etoposide at concentrations 20 and $200 \mu \mathrm{M}$ and BjorlingPoulsen et Issinger (4) induced apoptosis in HL-60 cells by incubation with $30 \mu \mathrm{M}$ etoposide for $5 \mathrm{~h}$.

Quantitative real-time RT-PCR analysis showed that expression level of BCL2 gene significantly decreased after $6 \mathrm{~h}$ of etoposide treatment in HL-60 cells. Whereas expression level of BAX significantly increased after both $6 \mathrm{~h}$ and $12 \mathrm{~h}$ of treatment.

These results indicate that etoposide induces apoptosis in HL-60 cells and morphological changes are accompanied by changes in expression of apoptosis-related genes BCL2 and BAX. Similar results as upregulation of BAX gene in HL-60 cells after treatment with etoposide and downregulation of BCL2 gene after treatment with topotecan and methotrexate reported Floros et al. $(12,11)$. Rózalski et al. (24) noted downregulation of BCL2 and upregulation of BAX in HL-60 cells after treatment with doxorubicin and amifostine. Floros et al. (13) reported about downregulation of BCL2 in HL-60 cells after cisplatin treatment.

\section{Conclusions}

Our findings show that etoposide, the topoizomerase II inhibitor, induce apoptosis in HL-60 cells. The expression level of proapoptotic gene BAX significantly increased after 6 and $12 \mathrm{~h}$ during etoposide treatment, whereas expression of antiapoptotic BCL2 decreased. On the contrary in Hep2 cells the expression of BCL2 significantly increased both $6 \mathrm{~h}$ and $12 \mathrm{~h}$ after etoposide treatment, whereas expression of BAX did not change. Those findings show the distinct reactions of Hep-2 and HL-60 cells to etoposide treatment and different upregulation or downregulation of apoptosisrelated genes BCL2 and BAX.

\section{Acknowledgements}

This work was supported by the Ministry of Education, Youth and Sports of the Czech Republic (MSM 00216275 02).

\section{References}

1. Bailly C. Topoisomerase I poisons and suppressors as anticancer drugs. Curr Med Chem. 2000;7(1):39-58.

2. Balasubashini MS, Karthigayan S, Somasundaram ST, Balasubramanian T, Rukkumani R, Menon VP. FV peptide induces apoptosis in HEp 2 and HeLa cells: an insight into the mechanism of induction. J Carcinog. 2006;5:27.

3. Baldwin EL, Osheroff N. Etoposide, topoisomerase II and cancer. Curr Med Chem Anticancer Agents. 2005;5(4):363-72.

4. Bjorling-PoulsenM, Issinger OG. cDNA array analysis of alterations in gene expression in the promyelocytic leukemia cell line, HL-60, after apoptosis induction with etoposide. Apoptosis. 2003;8(4):377-88

5. Cervinka M, Bereiter-Hahn J, Peychl J, Rudolf E, Cervinkov Z. The role of mitochondria in apoptosis induced in vitro. Gen Physiol Biophys. 1999;18:33-40.

6. Cervinka M, Cerman J, Rudolf E. Apoptosis in Hep2 cells treated with etoposide and colchicine. Cancer Detect Prev. 2004;28(3):214-26.

7. Duran N., Allahverdiyev AM, Cetiner S. Flow Cytometric Analysis of the Effects of Methotrexate and Vepesid on the HEp-2 Cell Cycle. Turk J Med Sci. 2001; $31: 187-192$.

8. Eliseev RA, Gunter KK, Gunter TE. Bcl-2 prevents abnormal mitochondrial proliferation during etoposide-induced apoptosis. Exp Cell Res. 2003;289(2): 275-81

9. Filippovich IV, Sorokina NI, Lisbona A, Chrel M, Chatal JF. Radiation-induced apoptosis in human myeloma cell line increases BCL-2/BAX dimer formation and does not result in BAX/BAX homodimerization. Int $\mathbf{J}$ Cancer. 2001; 92(5):651-60.

10. Finucane DM, Bossy-Wetzel E, Waterhouse NJ, Cotter TG, Green DR. Bax-induced caspase activation and apoptosis via cytochrome c release from mitochondria is inhibitable by Bcl-xL. J Biol Chem. 1999;274(4):2225-33.

11. Floros KV, Talieri M, Scorilas A. Topotecan and methotrexate alter expression of the apoptosis-related genes BCL2, FAS and BCL2L12 in leukemic HL-60 cells. Biol Chem. 2006;387(12):1629-33.

12. Floros KV, Thomadaki H, Florou D, Talieri M, Scorilas A. Alterations in mRNA expression of apoptosis-related genes BCL2, BAX, FAS, caspase-3, and the novel member BCL2L12 after treatment of human leukemic cell line HL60 with the antineoplastic agent etoposide. Ann N Y Acad Sci. 2006;1090:89-97.

13. Floros KV, Thomadaki H, Lallas G, Katsaros N, Talieri M, Scorilas A. Cisplatininduced apoptosis in HL-60 human promyelocytic leukemia cells: differential expression of BCL2 and novel apoptosis-related gene BCL2L12. Ann N Y Acad Sci. $2003 ; 1010: 153-8$

14. Higginbottom K, Jahnke U, Newland AC, Cotter FE, New alternative phosphorylation sites on the cyclin dependent kinase 1 /cyclin a complex in p53-deficient human cells treated with etoposide: possible association with etoposide-induced apoptosis. Apoptosis. 2007;12(10):1847-55.

15. Ikeguchi M, Hirooka Y, Kaibara N. Quantitative analysis of apoptosis-related gene expression in hepatocellular carcinoma. Cancer. 2002:95(9):1938-45.

16. Ikeguchi M, Nakamura S, Kaibara N. Quantitative analysis of expression levels of bax, bcl-2, and survivin in cancer cells during cisplatin treatment. Oncol Rep. 2002;9(5):1121-6.

17. Jakubowicz-Gil J, Paduch R, Gawron A, Kandefer-Szersze M. The effect of heat shock, cisplatin, etoposide and quercetin on Hsp27 expression in human normal and tumour cells. Folia Histochem Cytobiol. 2002;40(1):31-5.

18. Kluza J, Mazinghien R, Irwin H, Hartley JA, Bailly C. Relationships between DNA strand breakage and apoptotic progression upon treatment of HL-60 leukemia cells with tafluposide or etoposide. Anticancer Drugs. 2006;17(2):155-64

19. Kravtsov VD, Daniel TO, Koury MJ. Comparative analysis of different methodological approaches to the in vitro study of drug-induced apoptosis. Am J Pathol. 1999;155(4):1327-39.

20. Li P, Budihardjo I et al. Cytochrome $\mathrm{c}$ and dATP-dependent formation of Apaf1/caspase-9 complex initiates an apoptotic protease cascade. Cell. 1997;91(4): $479-89$

21. Livak KJ, Schmittgen TD. Analysis of relative gene expression data using realtime quantitative PCR and the 2(-Delta Delta C(T)) Method. Methods. 2001; 25(4):402-8

22. Oltvai ZN, Milliman CL, Korsmeyer SJ. Bcl-2 heterodimerizes in vivo with a conserved homolog, Bax, that accelerates programmed cell death. Cell. 1993;74(4): 609-19.

23. Parihar A, Parihar MS, Ghafourifar P. Significance of mitochondrial calcium and nitric oxide for apoptosis of human breast cancer cells induced by tamoxifen and etoposide. Int J Mol Med. 2008;21(3):317-24.

24. Rózalski M, Mirowski M, Balcerczak E, Krajewska U, Mynarski W, Wierzbicki R. Induction of caspase 3 activity, bcl-2 bax and $\mathrm{p} 65$ gene expression modulation in human acute promyelocytic leukemia HL-60 cells by doxorubicin with amifostine. Pharmacol Rep. 2005;57(3):360-6.

25. Rudolf E, Cervinka M. Membrane blebbing in cancer cells treated with various apoptotic inducers. Acta Medica. 2005;48(1):29-34

26. Rudolf E, Peychl J, Novak J, Cervinka M. Apoptosis - when the cells begin to dance. Front Biosci. 2000;5:F1-2 
27. Sargent JM, Elgie AW, Williamson CJ, Hill BT. Ex vivo effects of the dual topoisomerase inhibitor tafluposide (F 11782) on cells isolated from fresh tumo samples taken from patients with cancer. Anticancer Drugs. 2003;14(6) 467-73.

28. Singh S, Chhipa RR, Vijayakumar MV, Bhat MK. DNA damaging drugs-induced down-regulation of Bcl-2 is essential for induction of apoptosis in high-risk HPVpositive HEp-2 and KB cells. Cancer Lett. 2006;236(2):213-21.
29. Thomas D, Yang H, Boffa DJ et al. Proapoptotic Bax is hyperexpressed in isolated human islets compared with antiapoptotic Bcl-2. Transplantation. 2002;74(11):1489-96

30. Zuryn A, Grzanka A, Stepien A, Grzanka D, Debski R, Smolinski D. Expression of cyclin A in human leukemia cell line HL-60 following treatment with doxorubicin and etoposide: the potential involvement of cyclin A in apoptosis. Onco Rep. 2007;17(5):1013-9.

Submitted February 2008. Accepted August 2008.

\section{Corresponding author:}

RNDr. Dita Královcová, Department of Biological and Biochemical sciences, Faculty of Chemical - Technology, University of Pardubice, Štrossova 239, 53003 Pardubice, Czech Republic; e-mail: dita.kralovcova@upce.cz 